\title{
Planting of Eucalyptus in Malaysia
}

\author{
Ahmad Zuhaidi Yahya* \\ Research Fellowship, Forestry Biotechnology Division, FRIM, Malaysia \\ *Corresponding Author: Ahmad Zuhaidi Yahya, Research Fellowship, Forestry \\ Biotechnology Division, FRIM, Malaysia.
}

DOI: $10.31080 /$ ASAG.2020.04.0785
Received: January 17, 2020

Published: January 28, 2020

(C) All rights are reserved by Ahmad

Zuhaidi Yahya
The Malaysian Government through the Ministry of Plantation Industries and Commodity (KPPK) and Malaysian Timber Industrial Board (MTIB) with the support of various forestry agencies have recognized that forest plantation as a strategy to overcome the scarcity of timber supply in the near future. The existing natural forests is currently reducing its capability to continue meeting the increasing demand of log/timber for domestic wood processing industries. In an effort to reduce the reliance on natural forests as the main source of round logs, the government has realized the needs of continuous wood supply and encouraging the development of large-scale commercial forest plantations. Unlike the previous reforestation programmes, the Compensatory Forest Plantation Programme (CFPP) in 1980s, were fully implemented by the state government using funds available from soft loans, however the current programme involved the full participation of the private sectors currently involved with forestry operations and developments.

Under the current afforestation/reforestation programme, a number of natives and exotic were selected for planting, nevertheless only two of three species have been chosen for commercial planting including Latex Timber Clone, Acacias, Paraserianthes falcataria and Neolamarckia cadamba ((kelempayan/laran in Sabah and Sarawak). The other native Shorea roxburghii, is gaining the acceptance as one of the dipterocarp species identified and selected for plantation of a rotational period of at least 20 years, Until very recently, $A$. mangium was the most preferred species for being a robust tree able to grow on a variety of sites, good growth performance and relatively free from pests and diseases. However, after 25 years in operational, it is now confirmed that $A$. mangium and its hybrids are badly affected by fungi Ceratocystis in Sabah as well as in Peninsular Malaysia (Lee 2003). The seriousness of the situation has prompted the plantation investors to seek other alternative species to replace A. mangium. In Sabah, most of the planters have slowly shifted from planting Acacias to Eucalyptus species due to the wide spread occurrence of Ceratocystis disease which caused death to about 10 to $20 \%$ of the Acacia trees in plantations (Wong., et al. 2015). Among the Eucalyptus selected are mainly E. hybrid and E. pellita as these species are well known having high survival rate, wider range of adaptability with sites and favourable stem form.

Despite its potential as future plantation crop, the Eucalyptus species is still being evaluated and under consideration to be listed by the government, however, it is getting more importance as $E u$ calyptus plantation areas established were steadily increases by forestry companies especially in Sabah and Sarawak. Based on the latest progress, the Eucalyptus, have been widely accepted as the main species within the plantation programme and demonstrated an ability to grow quickly on often difficult sites and under conditions that might differ from those identified in their natural habitat. The most common Eucalyptus species planted are the Eucalyptus hybrid (E. urophylla X E. grandis) and Eucalyptus pellita.

\section{Species origin and utilization}

The hybrid was first introduced in Malaysia in the 2008 using clones selected from Southern China and was later planted in many parts including Sabah Softwood Berhad (Figure 1) and some parts in Peninsular Malaysia. While the E. pellita native to Papua New Guinea and Northern Australia originally introduced using seeds and being commercially planted in many parts of Sarawak as well in Sabah since 2012 onwards. Those early plantations are being converted as the Seed Production Areas (SPA) as source of planting materials mainly through seed supply and stem cuttings. The wood of both Eucalyptus is suitable for making products related with pulps, plywoods, furniture or as peeler logs.

Recent development and performance of Eucalyptus plantation

Eucalyptus is one of the most popular tropical tree plantation species. The genus Eucalyptus comprises more than 700 varieties of Eucalyptus trees (Harden 1991), however, 236 species of occurred in New South Wales, Australia. The species qualifies almost all the characteristics for commercial plantation species including rapid growth under plantation conditions, straight stems with limited branching, and suitable wood quality for particular uses and products. To some extent, selected Eucalyptus species are tolerant on a variety of soils and site conditions, and resistant to common pests and diseases. The recent research development by the Forestry Biotechnology, Forest Research Institute Malaysia (FRIM) on the planting suitability, growth and yield and its utilization aspects gave the forest plantation industry a new outlooks on the prospect of the species as the future plantation crops.

A sample of 20 trees extracted from a 5-year-old E. hybrid stands, established in 2013 between FRIM and Forestry Department Peninsular Malaysia (FDPM) in Bukit Sedanan Forest Reserve, Malacca were processed as peeler logs to be manufactured as plywood, marine ply and container boards. The results obtained from the trial processing have shown the actual potential of the logs from the hybrid and to encourage investors in forest plantations using this new source of raw materials. 


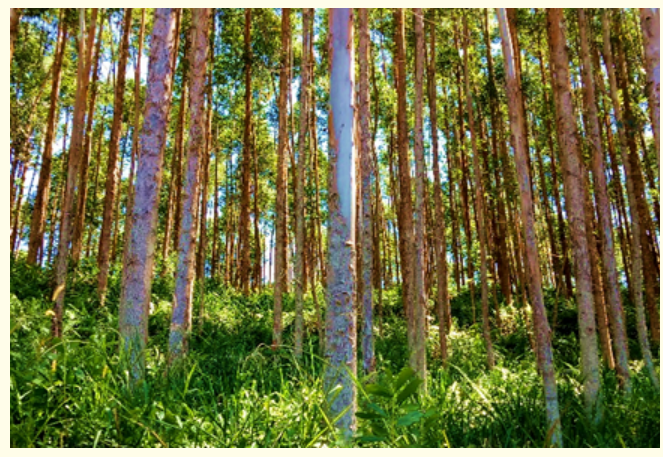

Figure 1: 10-year-old E. hybrid, Sabah Softwood Berhad (2018).

\section{Assets from publication with us}

- Prompt Acknowledgement after receiving the article

- Thorough Double blinded peer review

- Rapid Publication

- Issue of Publication Certificate

- High visibility of your Published work

Website: www.actascientific.com/

Submit Article: www.actascientific.com/submission.php Email us: editor@actascientific.com

Contact us: +91 9182824667
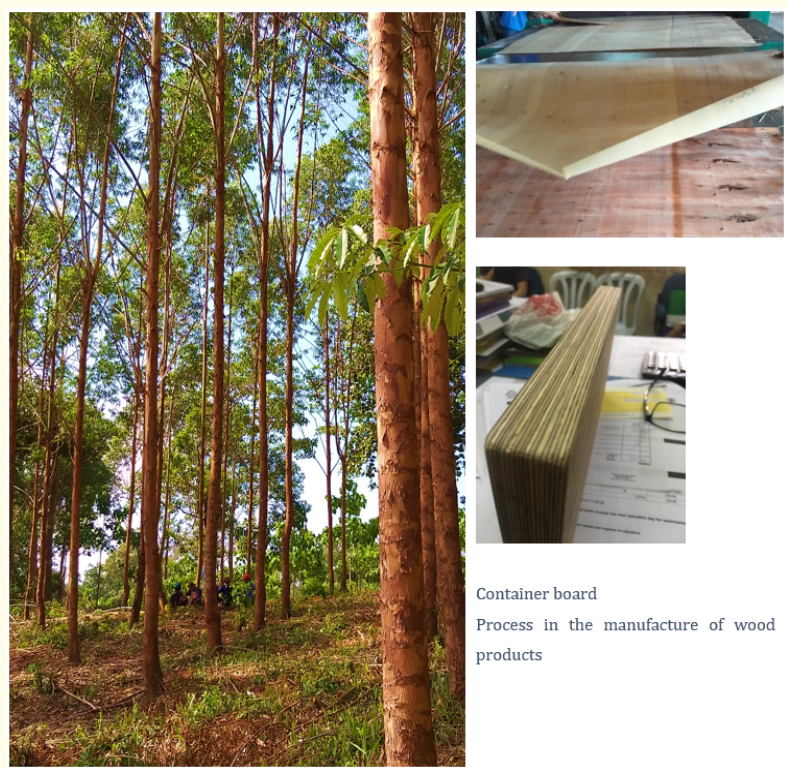

Container board

Process in

products

Figure 2: 5-year-old Eucalypts hybrid (2018), Bukit Sedanan F.R.

The trial planting by FRIM in Bukit Sedanan F.R, may not representative of the actual potential of the Eucalyptus hybrid planted in the country, however the growth and yield, suitability and adaptation of the species in the current site (Figure 1 and 2) as well as those planted in Sabah clearly shown the potential of the species for large scale planting in the country. At 5 years after planting, the mean diameter at breast height (dbh over bark) and clear bole height were between 20 and $22 \mathrm{~cm}$; and between 7 and $10 \mathrm{~m}$ respectively. While in Sabah, the average dbh over bark varies from 18 to $24 \mathrm{~cm}$, based on quick assessment of the stand. These dbh sizes and clear bole length suffice the requirements for peeler logs in the manufacture of plywood or any improved wood products. As an alternative E. pellita introduced from Papua New Guinea remains the next potential species, as the trees possessed wood quality much denser than the hybrid, utilized mainly for sawn wood and furniture. Due to its versatility and usage, more than 50,000 ha have been established especially in Sarawak, Sabah and Peninsular Malaysia. Based on the current progress of the planting, has provided the investors and government agencies to move forward in commercializing the species. 